\title{
Strategies to Control Loropetalum Decline in Central Florida ${ }^{1}$
}

Amy L. Shober and Gary L. Leibee ${ }^{2}$

\section{Introduction}

Loropetalum chinensis (also called Chinese fringebush or Chinese witch hazel) is a woody ornamental plant that is commonly used in the landscape in Florida. Loropetalum is native of China, Japan and the Himalayas and comes in several cultivars with variable foliage and flower color. The cultivar Ruby has been a popular choice in Florida landscapes because, in addition to its attractive burgundy foliage and beautiful pink flowers, the Ruby cultivar grows to 4-6 ft high and wide compared to an average 8-10 ft for other cultivars (Fig. 1).

Loropetalum 'Ruby' has long been considered a fairly low maintenance landscape plant with few insect or disease problems. However, in recent years, there have been increasing reports and complaints of unexplained decline, especially in central Florida. The most commonly reported symptoms of decline include new growth that is stunted or deformed (Fig. 2), curling of leaves, defoliation (Fig. 3), and in extreme cases, plant death. Possible explanations for Loropetalum decline include eriophyid mites, nutrient

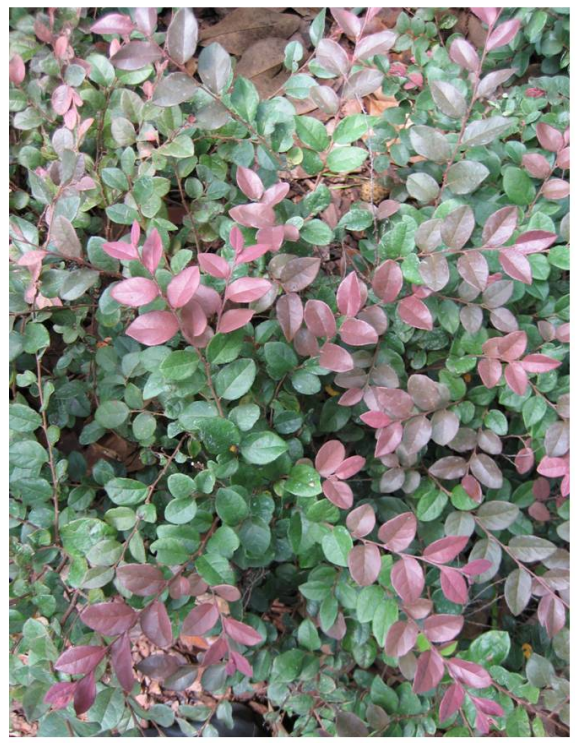

Figure 1. Healthy Loropetalum 'Ruby' plant.

deficiency (especially micronutrients), root rot, nematodes and salt toxicity.

Soil and tissue sample analysis from several areas in Orange County experiencing Loropetalum decline suggested a potential micronutrient deficiency $(\mathrm{Cu}, \mathrm{Zn}, \mathrm{Mn}$, or B) or eriophyid mite infestation. In order to identify possible causes of

1. This document is SL 255 one of a series of the Soil and Water Science Department, Florida Cooperative Extension Service, Institute of Food and Agricultural Sciences, University of Florida. Original publication date October 2007. Visit the EDIS Web Site at http://edis.ifas.ufl.edu.

2. Amy L. Shober, assistant professor, Gulf Coast Research and Education Center; and Gary L. Leibee, associate professor, Mid-Florida Research and Education Center. Florida Cooperative Extension Service, University of Florida, IFAS, Gainesville, FL 32611.

The Institute of Food and Agricultural Sciences (IFAS) is an Equal Opportunity Institution authorized to provide research, educational information and other services only to individuals and institutions that function with non-discrimination with respect to race, creed, color, religion, age, disability, sex, sexual orientation, marital status, national origin, political opinions or affiliations. U.S. Department of Agriculture, Cooperative Extension Service, University of Florida, IFAS, Florida A. \& M. University Cooperative Extension Program, and Boards of County Commissioners Cooperating. Larry Arrington, Dean 


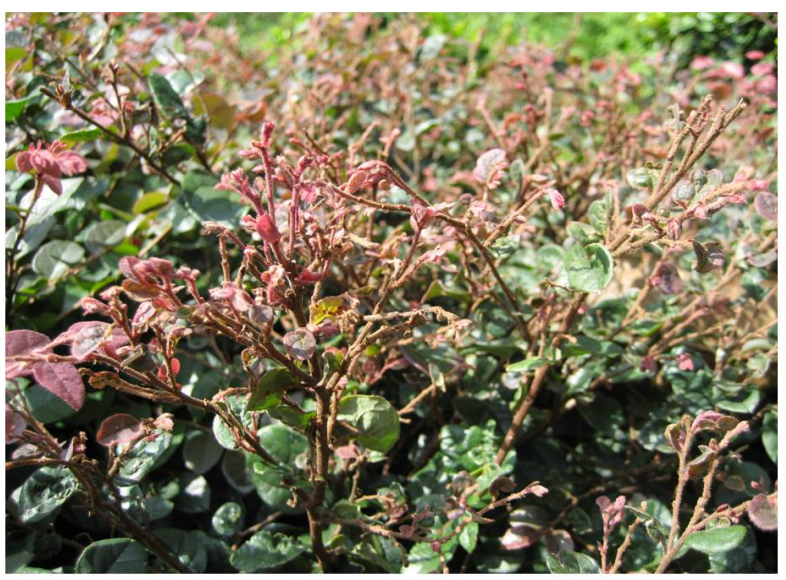

Figure 2. Stunted and deformed new growth on Loropetalum 'Ruby' in a commercial landscape in Orange County, FL.

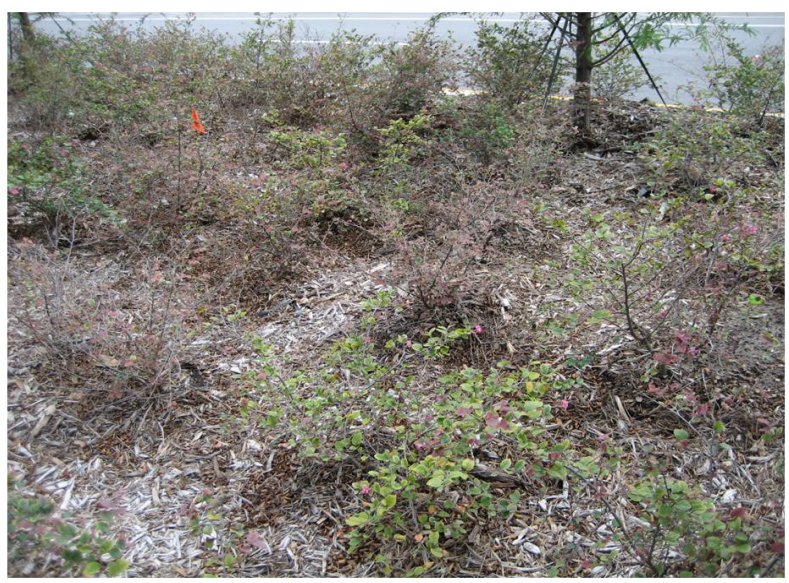

Figure 3. Severe defoliation of Loropetalum 'Ruby' plants from a residential median area in Orange County, FL.

decline and develop management methods to control plant decline, two research studies were conducted. The first study was conducted at the Mid-Florida Research and Education Center (MREC) in Apopka, FL. This study evaluated the use of a carbaryl miticide (Sevin) and several foliar fertilizer treatments (Table 1) on Loropetalum growth and plant quality using 180 potted plants showing symptoms of decline. The fertilizer treatments included $\mathrm{Cu}$ (as copper sulfate pentahydrate) at a high and low rate, $\mathrm{Cu}$ (as Kocide 2000) at the label rate, Mn (as manganese sulfate), $\mathrm{Zn}$ (as zinc sulfate), B (as sodium pentaborate - Borax), and Peters S.T.E.M. at the high label rate. All sulfate solutions were mixed with hydrated lime to adjust $\mathrm{pH}$. There was also an untreated control for a total of eight fertilizer treatments. Each fertilizer treatment was applied once to 18 individual plants, where nine of those plants were treated with the carbaryl miticide monthly and nine received no miticide.

Results indicated that there were no significant effects of miticide or foliar fertilizer on plant growth (height $\mathrm{x}$ width $\mathrm{x}$ breadth) at any time during the two month evaluation. There was, however, a significant fertilizer treatment effect on plant quality evaluated at 3 and 7 weeks after treatment (Table 2). Plants sprayed with the foliar $\mathrm{Cu}$ treatments tended to be the healthiest with slight to no mite damage and good to fair (sellable) plant quality (Fig. 4). The quality of the $\mathrm{Cu}$ treated plants was always significantly better than the untreated plants, and in many cases better than plants sprayed with B or Peters STEM. In all cases, the use of Sevin miticide did not affect the performance of any foliar fertilizers. However, a decline in plant quality at 12 weeks after treatment suggests that the effects of the foliar fertilizers will decrease with time.

An additional study was conducted at the Gulf Coast REC in Wimauma, FL to evaluate the potential for amending soil with $\mathrm{Cu}$ to prevent decline of Loropetalum Ruby. Soils were amended with copper sulfate $\left(\mathrm{CuSO}_{4} \cdot 5 \mathrm{H}_{2} \mathrm{O}\right)$ at $0,2.5,6.25$ and $10 \mathrm{lbs} \mathrm{Cu}$ $\mathrm{ac}^{-1}$ or with a micronutrient mix (5 lb fertilizer 1000 $\mathrm{ft}^{-2}$ ). However, at 16 weeks after treatment there is no evidence that soil $\mathrm{Cu}$ fertilization has had any effect on plant growth (height $\mathrm{x}$ width $\mathrm{x}$ breadth), quality or density.

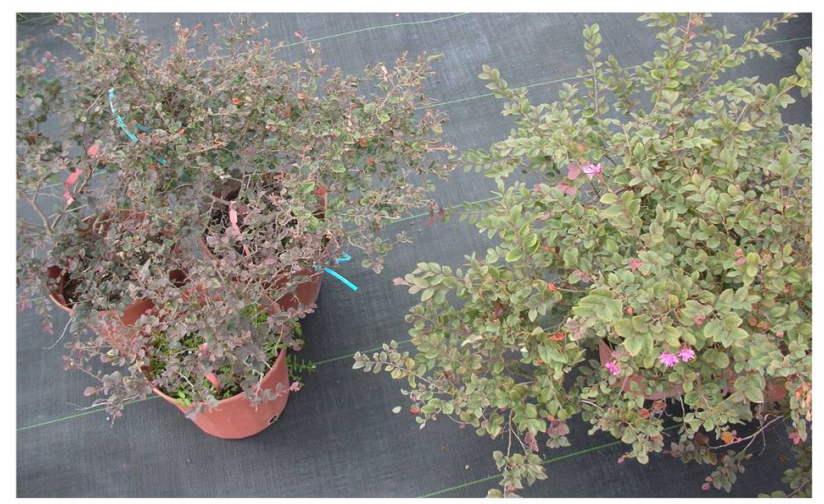

Figure 4. Comparison of Loropetalum 'Ruby' quality between plants receiving no foliar copper fertilizer (left) and plants receiving the high copper sulfate/hydrated lime foliar fertilizer treatment (right). Photo was taken ten weeks after fertilizer and miticide treatments were applied. 


\section{Recommendations}

We currently recommend planting 'Burgundy', 'Plum', or another cultivar with similar characteristics (e.g., red/purple new growth, pink flowers) to 'Ruby', since there have been no reports of widespread decline for these cultivars in Florida. The following tips will help you to identify different cultivars. Loropetalum 'Ruby' is a small (3-5 ft tall), rounded plant with leaves that are more rounded and pink flowers that bloom year round (Fig. 5).

Loropetalum 'Burgundy' (also called 'Sizzling Pink') will stand more upright than 'Ruby' and grows to be 6-10 ft tall. Loropetalum 'Burgundy' has elongated, pointed leaves that turn bright red in the fall and flowers that bloom intermittently (Fig. 6).

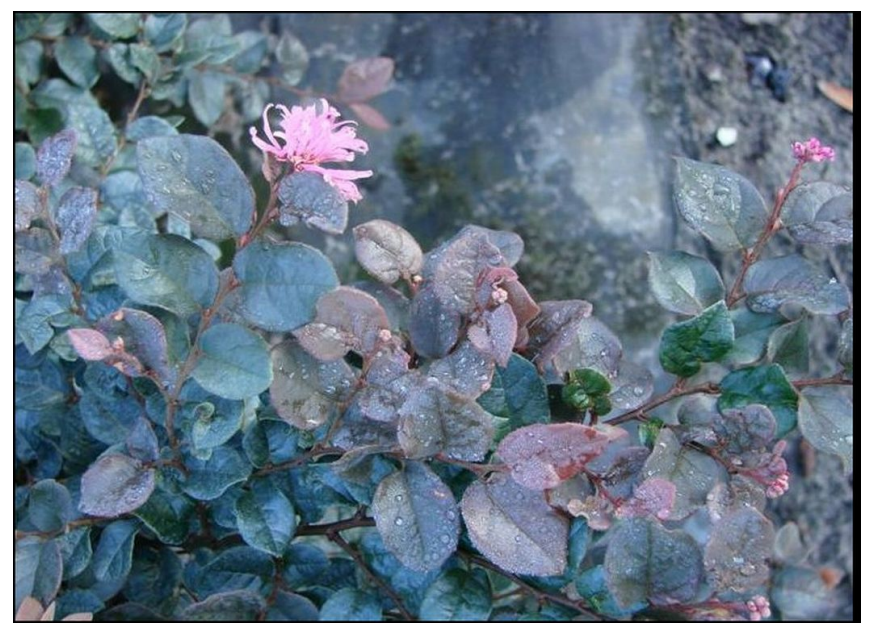

Figure 5. Loropetalullm 'Ruby' has smaller more rounded leaves and pink flowers that bloom year round.

\section{Loropetalum 'Plum' (also known as 'Hines} Purpleleaf', 'Plum Delight' or 'Pizzazz') has dark foliage and tends to have smaller, darker flowers (Fig. 7). This cultivar will grow to be 6-8 ft tall. While other cultivars tend to grow larger than 'Ruby', proper pruning will help to maintain them at a smaller size.

For existing plantings of Loropetalum Ruby, our research results suggest that quarterly foliar applications of $\mathrm{Cu}$ could improve plant quality in the landscape. The amount of $\mathrm{Cu}$ to apply will vary based on the source of $\mathrm{Cu}$ that will be applied. This is because the plant availability of $\mathrm{Cu}$ is dependent on the efficiency of the active $\mathrm{Cu}$ compound to release $\mathrm{Cu}^{2+}$ which occurs roughly in the following order: copper sulfate pentahydrate (no lime additions) >

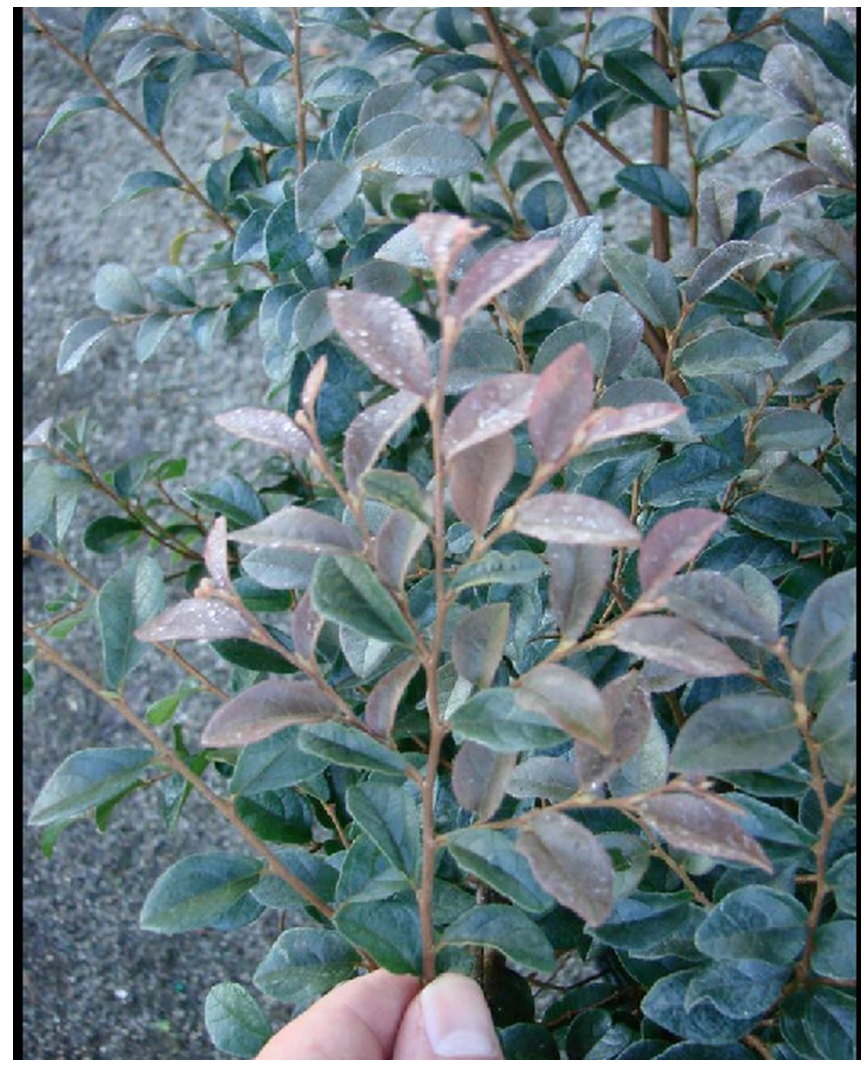

Figure 6. Loropetalum 'Burgundy' (also called 'Sizzling Pink') has elongated, pointed leaves and flowers that bloom intermittently

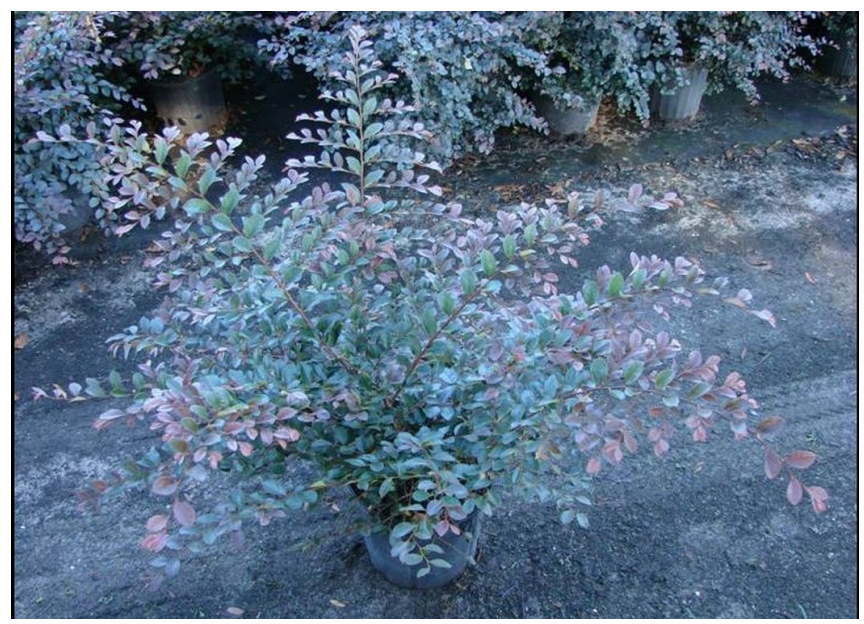

Figure 7. Loropetalum 'Plum' (also known as 'Hines Purpleleaf'. 'Plum Delight' or 'Pizzazz') has dark foliage withsmaller, darker flowers.

copper hydroxide > copper tallate copper ammonium complex tribasic copper sulfate.

For best results, we suggest application of a 5-2.5-100 Cu/lime mixture. To create this mixture, add $5 \mathrm{lbs}$ powdered copper sulfate pentahydate and $2.5 \mathrm{lbs}$ fresh hydrated lime to 100 gallons of water. 
Spray each individual plant thoroughly. Remember that several common fungicides utilize $\mathrm{Cu}$ hydroxide $\left(\mathrm{Cu}(\mathrm{OH})_{2}\right)$ as the active ingredient (e.g., Kocide 2000, Champion WP, Agri Star Nu Cop). If you are already treating Loropetalum for a fungal pest, you will not need to apply an additional source of $\mathrm{Cu}$ to control decline.

When using any foliar $\mathrm{Cu}$ treatment, avoid spraying surrounding plants as phytotoxicity may occur. These materials can also cause damage to metal surfaces such as cars, lawn furniture, etc. In addition, applicators should wear appropriate personal protective equipment when applying foliar $\mathrm{Cu}$ sprays. 
Table 1. Concentrations of trace elements applied foliarly to each plant in $250 \mathrm{~mL}$ of solution.

\begin{tabular}{lccccccc|}
\hline \hline Treatment & $\mathrm{Cu}$ & $\mathrm{Zn}$ & $\mathrm{Mn}$ & $\mathrm{B}$ & $\mathrm{Mo}$ & $\mathrm{Fe}$ \\
\hline CuSo4 - Low & 158 & & 0.0 & 0.0 & 0.0 & 0.0 & 0.0 \\
CuSo4 - High & 318 & 0.0 & 0.0 & 0.0 & 0.0 & 0.0 \\
Kocide 2000 & 1575 & 0.0 & 0.0 & 0.0 & 0.0 & 0.0 \\
MnSO4 & 0.0 & 0.0 & 185 & 0.0 & 0.0 & 0.0 \\
ZnSO4 & 0.0 & 328 & 0.0 & 0.0 & 0.0 & 0.0 \\
Borax & 0.0 & 0.0 & 0.0 & 22.0 & 0.0 & 0.0 \\
Peters STEM & 4.8 & 6.8 & 12.0 & 2.0 & 0.1 & 11.3 \\
Control & 0.0 & 0.0 & 0.0 & 0.0. & 0.0. & 0.0. \\
\hline \hline
\end{tabular}

Table 2. Loropetalum plant quality ratings at 2 and 4 weeks after receiving fertilizer and miticide treatments. Values with the same letter are not statistically different. Plant quality ratings were as follows: $1=$ good; $2=$ fair $; 3=$ moderate; $4=$ poor; $5=$ very poor.

\begin{tabular}{|lcc|}
\hline \hline & \multicolumn{2}{c|}{ Quality } \\
\cline { 2 - 3 } Fertilizer Treatment & $\begin{array}{c}2 \text { weeks after } \\
\text { treatment }\end{array}$ & $\begin{array}{c}4 \text { weeks after } \\
\text { treatment }\end{array}$ \\
\hline CuSO4 - Low & $1.6 \mathrm{a}$ & $1.8 \mathrm{ab}$ \\
CuSO4 - High & $1.3 \mathrm{a}$ & $1.6 \mathrm{a}$ \\
Kocide 2000 & $1.2 \mathrm{a}$ & $1.7 \mathrm{a}$ \\
MnSO4 & $3.1 \mathrm{~b}$ & $2.8 \mathrm{bc}$ \\
ZnSO4 & $2.8 \mathrm{~b}$ & $2.5 \mathrm{bc}$ \\
Borax & $3.2 \mathrm{bc}$ & $3.4 \mathrm{~cd}$ \\
Peters STEM & $3.5 \mathrm{bc}$ & $3.2 \mathrm{~cd}$ \\
Control & $4.1 \mathrm{c}$ & $3.4 \mathrm{~cd}$ \\
\hline \hline
\end{tabular}

